\title{
Aplastic Anemia Associated with Oral Terbinafine: A Case Report and Review of the Literature
}

\section{Oral Terbinafin İlişkili Aplastik Anemi: Bir Olgu Sunumu ve Literatür Derlemesi}

\author{
Bülent Kantarcıoğlu1, Hüseyin Kemal Türköz², Güven Yılmaz³, Funda Pepedil Tanrıkulu3, \\ Işık Kaygusuz Atagündüz ${ }^{3}$, Cafer Adıgüzel3, Tülin Fıratlı Tuğlular3 \\ 1Okmeydanı Training and Research Hospital, Clinic of Hematology, İstanbul, Turkey \\ ${ }^{2}$ Marmara University Faculty of Medicine, Department of Pathology, İstanbul, Turkey \\ 3Marmara University Faculty of Medicine, Department of Hematology, İstanbul, Turkey
}

\begin{abstract}
:
Onychomycosis (OM) is a common fungal infection of the toenails and/or fingernails that is highly prevalent in the general population and also responsible for significant morbidity. OM is caused by dermatophytes, nondermatophytic molds, or yeast. Today systemic antifungal agents are considered as the gold standard for all types of OM. Here we report a case of aplastic anemia associated with oral terbinafine use and a review of the literature on hematological toxicities associated with terbinafine.

Key Words: Onychomycosis, Terbinafine, Aplastic anemia, Hematological toxicity, Pancytopenia, Adverse events

Özet:

Onikomikoz (OM) el ve ayak tırnaklarının sık görülen fungal enfeksiyonudur. Genel toplumda prevalansı yüksek bir hastalık olması nedeniyle önemli morbiditeye yol açmaktadır. OM dermatofitler, nondermatofitik küf mantarları veya mayalar ile ortaya çıan hastalıklardır. Günümüzde onikomikozun tedavisinde sistemik antifungal ajanlar tüm OM tiplerinde altın standart tedavi olarak kabul edilmektedir. Biz burada, oral terbinafin kullanımı sırasında gelişen bir aplastik anemi olgumuzu ve literatürde terbinafine ile ilişkilendirilmiş olan hematolojik toksisitelerin derlemesini sunuyoruz.
\end{abstract}

Anahtar Sözcükler: Onikomikoz, Aplastik anemi, Terbinafin, Hematolojik toksisite, Pansitopeni, Yan etkiler

\section{Introduction}

Onychomycosis is a very frequent fungal nail infection. The prevalence can be as high as $28 \%-40 \%$, especially in elderly populations. Terbinafine is an antifungal agent with both fungicidal and fungistatic properties, which is highly effective and is the most frequently used agent in onychomycosis. Oral terbinafine is generally well tolerated with minimal reports of serious drug reactions. These rare adverse events are mostly reported as case presentations, and it is important to be familiar with them in order to be able to evaluate the risk and inform patients accordingly $[1,2,3]$. Here we report a case of aplastic anemia (AA) associated with oral terbinafine use and a review of the literature on hematological toxicities associated with terbinafine. Written informed consent was obtained from the patient and her husband for publication of this manuscript and accompanying images.

Address for Correspondence: Bülent KANTARCIOĞLU, M.D.,

Okmeydanı Training and Research Hospital, Clinic of Hematology, İstanbul, Turkey

Phone: +90 5325476208 E-mail: bulentkantarcioglu@gmail.com 


\section{Case Presentation}

A 41-year-old female presented with malaise, severe fatigue, nausea, and vaginal bleeding in April 2011. In her past history she was healthy, except that she reported taking terbinafine pills for 8 weeks for the treatment of longstanding recurrent toenail onychomycosis. She did not report any immune reactions or allergies to any drugs or substances. Her previous gynecological examination was normal, with a normal $\beta$-human chorionic gonadotropin level. Her complete blood count (CBC) revealed pancytopenia with white blood cell count of $3.2 \times 109 / \mathrm{L}$, absolute neutrophil count of $0.8 \times 109 / \mathrm{L}$, hemoglobin of $7.4 \mathrm{~g} / \mathrm{dL}$, and platelet count of $34 \times 10^{9} / \mathrm{L}$. Her physical examination was unremarkable with no evidence of lymphadenopathy or organomegaly, except for a few petechiae and ecchymoses on bilateral legs. Peripheral blood smear was consistent with pancytopenia. Reticulocyte count was 0.7. Liver enzymes were elevated [AST: $61 \mathrm{U} / \mathrm{L}(\mathrm{N}: 10-37 \mathrm{U} / \mathrm{L})$, ALT: 117 U/L (N: 10-40 U/L), ALP: 434 U/L (N: 0-270 U/L), GGT: $471 \mathrm{U} / \mathrm{L}$ (N: 7-49 U/L)]. Renal function tests and lactate dehydrogenase were normal. Bone marrow aspiration and biopsy revealed severe reduction of all cell lineages without evidence of neoplastic infiltration, dysplasia, or fibrosis. The counted cellularity was $5 \%$ in bone marrow. Bone marrow karyotype analysis was normal. A gastroenterology consultation performed for the liver enzyme abnormalities did not provide an etiologic factor, pointing toward drug-induced hepatitis. Further work-ups, including levels of vitamin B12 and folate; neck, chest, and abdominopelvic computerized tomography; serology and polymerase chain reaction (PCR) tests for viral hepatitis, human immunodeficiency, Epstein-Barr virus, parvovirus B19, and cytomegalovirus; FLAER test for paroxysmal nocturnal hemoglobinuria; antinuclear antibody test; HLA-DRB1*15; and quantiferon test for tuberculosis, were all negative. The patient was diagnosed with AA, which was not severe at that time. Terbinafine treatment was stopped. Due to the use of a drug with probable hematologic toxicity, follow-up with supportive care was planned for the patient. During 3-4 weeks of follow-up time, blood values worsened with the need for erythrocyte and thrombocyte transfusions, in accordance with very severe AA (SAA). She did not have a matched related donor for transplantation. After confirming the diagnosis with a second bone marrow biopsy, she received rabbit antithymocyte globulin (ATG) plus cyclosporine-A (CYC). The clinical outcome after ATG + CYC was poor due to transient worsening of hematopoiesis and infectious complications. She spent 3 months in the hospital with perianal abscess, invasive aspergillosis, zoster virus reactivation, and several catheter infections. She required physical and psychological rehabilitation. Fortunately, the blood values began to recover at the end of the fourth month and full hematologic recovery was achieved at the end of the sixth month. The patient is still in complete remission after 18 months of ATG + CYC treatment (Figures 1 and 2).

\section{Discussion and Review of the Literature}

Onychomycosis refers to all fungal infections of the nails. It is difficult to cure, has high recurrence rates, and can significantly affect a patient's quality of life. Topical therapies are generally ineffective, and today treatment with systemic antifungal agents is accepted as the gold standard method for onychomycosis. In clinical trials, continuous terbinafine has repeatedly demonstrated higher efficacy when compared to other antifungal treatments. The recommended dosage for the treatment of onychomycosis is $250 \mathrm{mg}$ /day orally for 12 weeks for toenails and 6 weeks for fingernails $[1,2,3]$.

Oral terbinafine is generally well tolerated with minimal reports of serious drug reactions. Two large-scale postmarketing surveillance studies showed that the incidence of serious

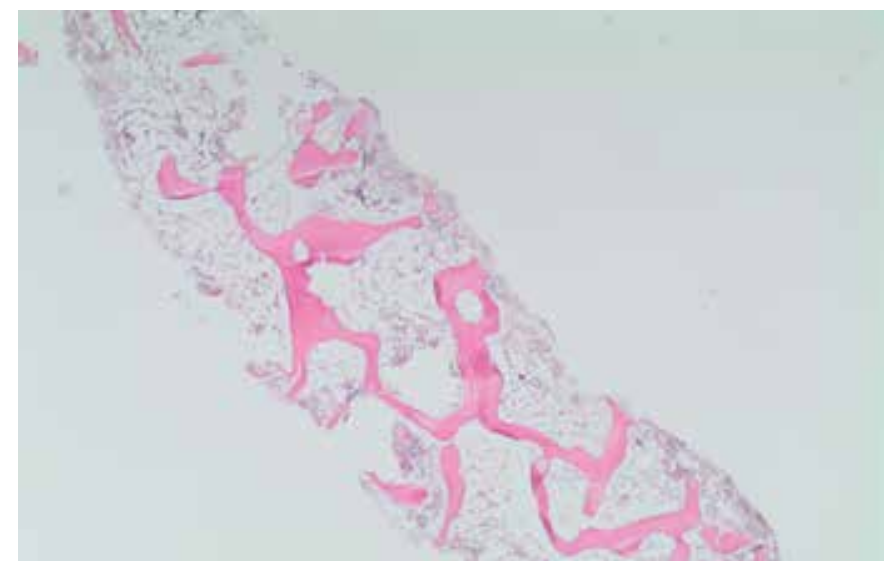

Figure 1. Bone marrow trephine biopsy: low cellularity in the bone marrow consistent with aplastic anemia (H\&E, 20x).

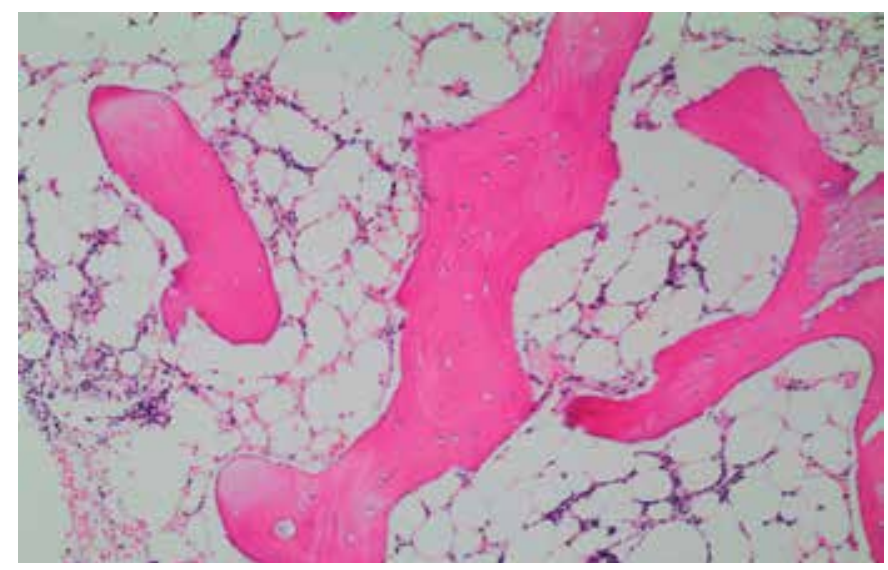

Figure 2. Bone marrow trephine biopsy: a few hematopoietic cells intermixed with lymphocytes and plasmocytes in interstitial areas (H\&E, 100x). 

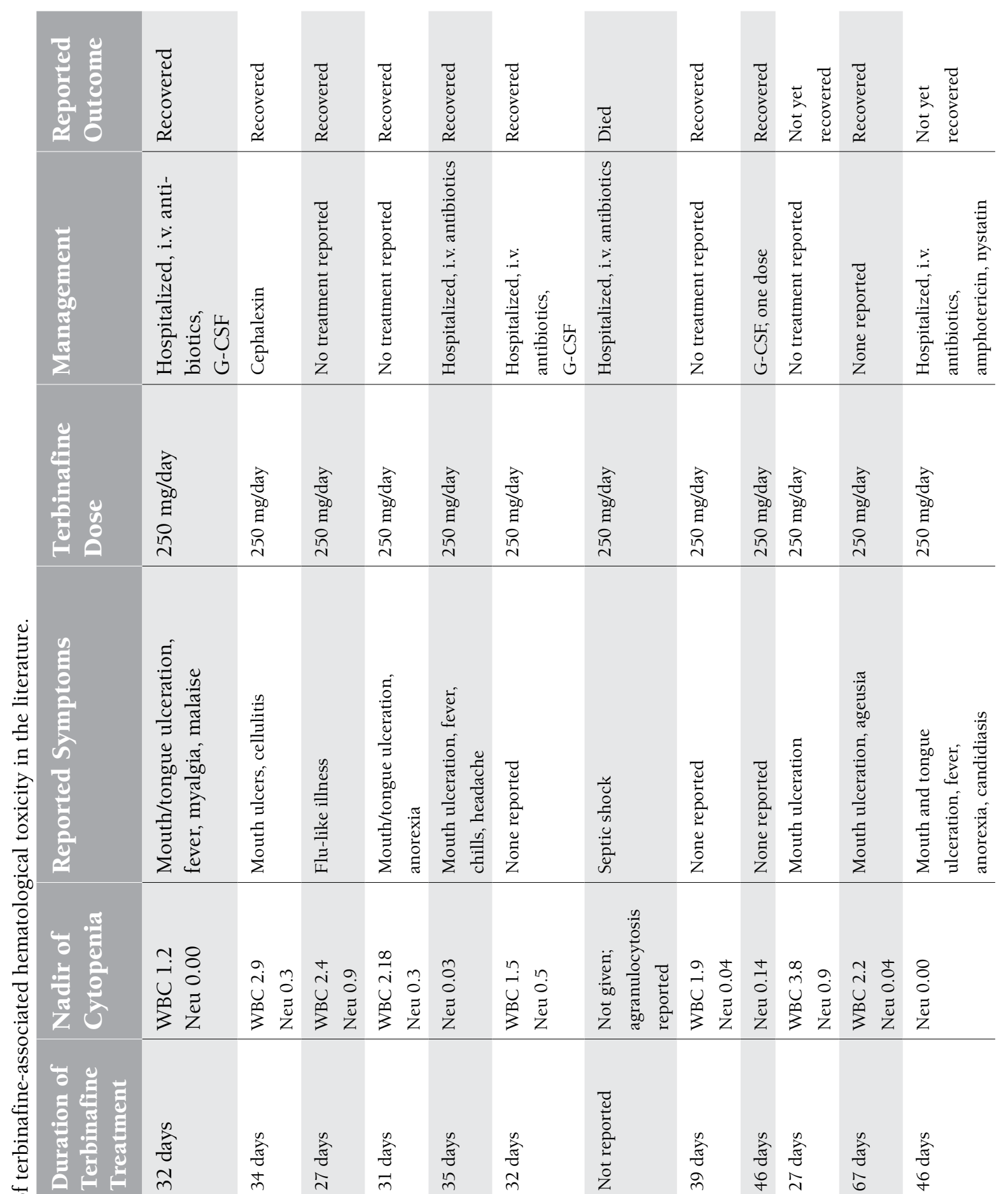

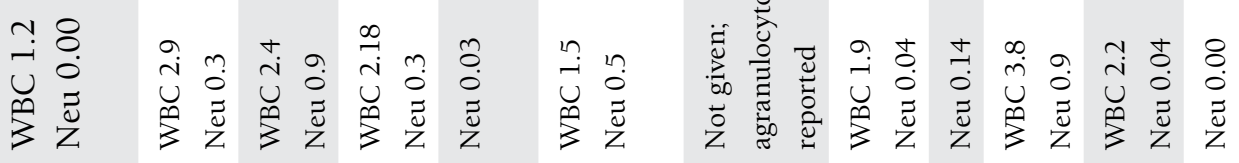

\begin{tabular}{|c|c|c|c|c|c|c|c|c|c|c|c|}
\hline 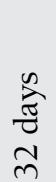 & $\begin{array}{c}\text { ț } \\
\text { ț } \\
+\end{array}$ & 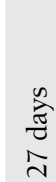 & $\begin{array}{l}\text { है } \\
\text { है } \\
\vec{m}\end{array}$ & 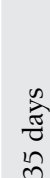 & 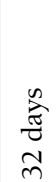 & $\begin{array}{l}\text { J } \\
0 \\
0 \\
0 \\
0 \\
0 \\
Z\end{array}$ & 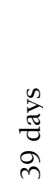 & 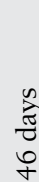 & $\begin{array}{l}\stackrel{0}{\tilde{J}} \\
\stackrel{\sim}{N}\end{array}$ & 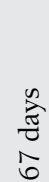 & 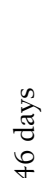 \\
\hline
\end{tabular}

新

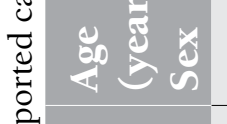

紫

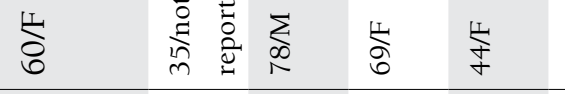

i

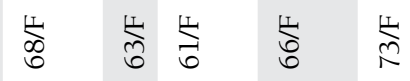



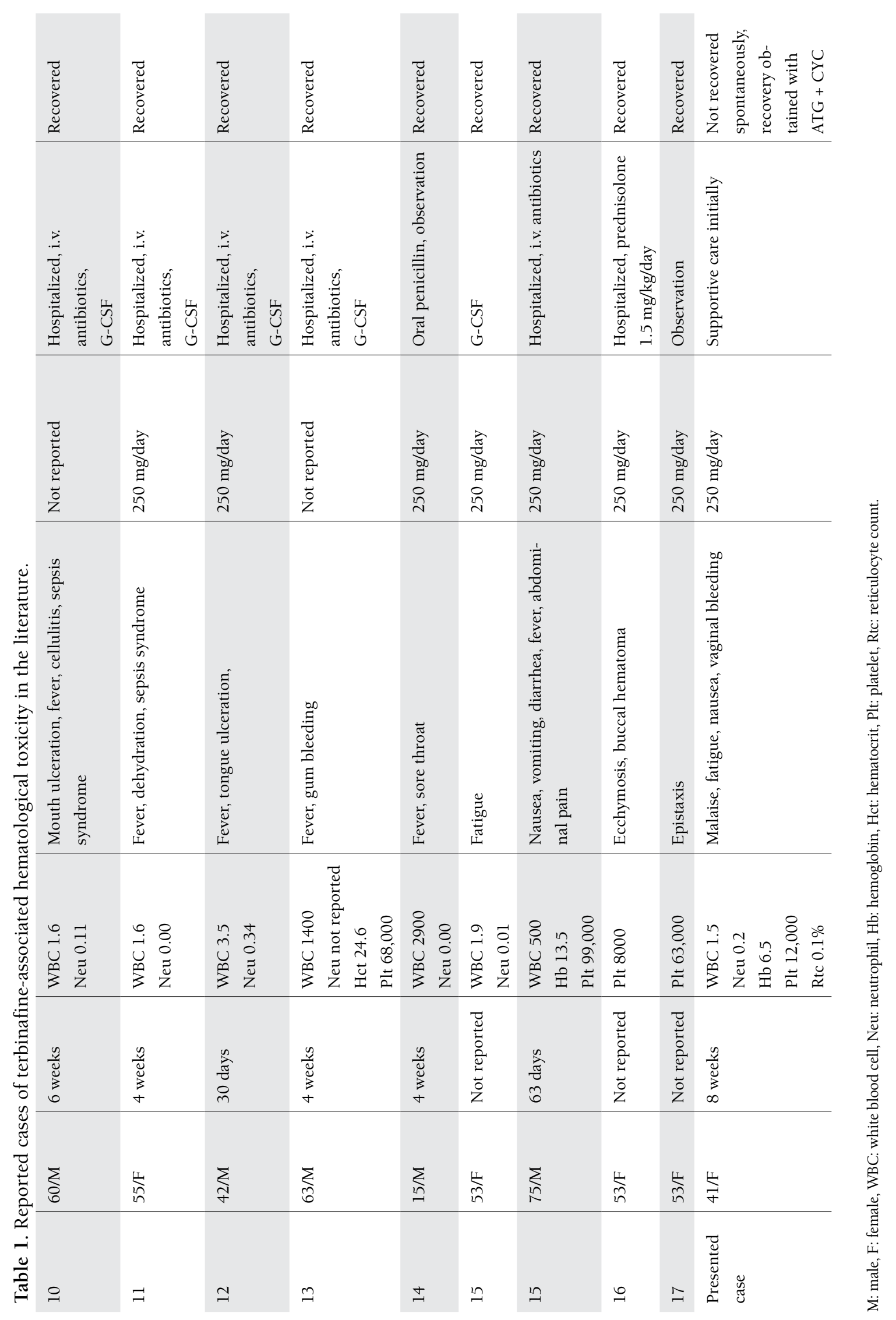
side effects was $<1 \%[4,5]$. In contrast, 2 studies of registry data from Austria and Denmark drew attention to blood dyscrasias associated with terbinafine [6,7]. Notable adverse events have been reported, including hepatitis requiring liver transplantation [8], drug-induced lupus reactions, severe skin reactions such as Stevens-Johnson syndrome, and, much less often, neutropenia/agranulocytosis and thrombocytopenia $[9,10,11,12,13,14,15,16,17]$. To our knowledge, ours is the first reported case of AA associated with terbinafine use.

AA is usually diagnosed within the setting of pancytopenia and hypocellular bone marrow when other diseases are excluded. SAA is almost always fatal if untreated. Once SAA is established, therapy should not be delayed in the hope of spontaneous recovery $[18,19]$.

Many drugs have been associated with AA. The vast majority of patients exposed to these drugs do not develop $\mathrm{AA}$ and the reason for idiosyncratic reactions is unknown. AA can develop as a direct response to exposure, but it can also develop indirectly through immune-mediated mechanisms. P-glycoprotein (P-gp), the MDR-1 gene product, and the multidrug resistance-associated protein are energy-dependent transmembrane efflux pumps for a variety of lipophilic drugs. Underexpression of P-gp in normal cells might allow cytoplasmic accumulation of drugs and enhance their toxic effects. Two studies found that P-gp activity was decreased in patients with AA; levels were lowest in a subgroup with druginduced AA $[20,21]$. In our case, the prolonged use of the highly lipophilic agent terbinafine might have caused direct toxicity, leading to AA.

Additionally, in a recently published study, the release of IL- 8 and TNF $\alpha$ was significantly increased by treatment with terbinafine, which can explain how terbinafine may also cause immune-mediated injury [22]. Lupus-like reactions reported with terbinafine use may be an additional evidence of immune-mediated injury as an underlying mechanism. However, in most cases, the trigger of the mechanism of AA remains unclear. Historically, drug-induced AA has not been easily distinguished from idiopathic forms of the disease since causality is difficult to establish [23].

A review of hematologic toxicities associated with the use of terbinafine showed that the duration of terbinafine exposure leading to hematological toxicity is almost 1 month; the degree of cytopenia can be severe and patients mostly presented with infectious complications requiring hospitalization. While the clinical outcome was reversible in most cases, our patient required additional treatment with a high burden of risk and complications (Table 1).

In conclusion, keeping in mind the slow and persistent course of onychomycosis requiring long-term treatment, the high rate of success achieved with terbinafine, and the wide range of the population receiving terbinafine treatment, we advise detailed information of patients in regard to adverse events and we recommend monitorization of $\mathrm{CBC}$ at baseline and every month during terbinafine treatment. To our knowledge, this is the first case report of irreversible SAA following treatment with terbinafine that required immunosuppressive treatment with ATG + CYC. This case highlights the need for routine blood count monitoring during treatment with terbinafine. In these patients, clinicians should consider the rare incidence of SAA when there is agranulocytosis or pancytopenia.

\section{Conflict of Interest Statement}

The authors of this paper have no conflicts of interest, including specific financial interests, relationships, and/or affiliations relevant to the subject matter or materials included.

\section{References}

1. Shemer A. Update: medical treatment of onychomycosis. Dermatol Ther 2012;25:582-593.

2. Grover C, Khurana A. An update on treatment of onychomycosis. Mycoses 2012;55:541-551.

3. Van Duyn GL, Elewski BE. Recent updates in oral terbinafine: its use in onychomycosis and tinea capitis in the US. Mycoses 2011:54:679-685.

4. Hall M, Monka C, Krupp P, O'Sullivan D. Safety of oral terbinafine: results of a postmarketing surveillance study in 25,884 patients. Arch Dermatol 1997;133:1213-1219.

5. O'Sullivan DP, Needham CA, Bangs A, Atkin K, Kendall FD. Postmarketing surveillance of oral terbinafine in the UK: report of a large cohort study. Br J Clin Pharmacol 1996;42:559-565.

6. ADRAC. Terbinafine and blood dyscrasias. Aust Adverse Drug React Bull 2004;23:19.

7. Bangsgaard N, Saunte DM, Folkenberg M, Zachariae C. Serious adverse events reporting on systemic terbinafine: a Danish register-based study. Acta Derm Venereol 2011;91:358-359.

8. Perveze Z, Johnson MW, Rubin RA, Sellers M, Zayas C, Jones JL, Cross R, Thomas K, Butler B, Shrestha R. Terbinafineinduced hepatic failure requiring liver transplantation. Liver Transpl 2007;13:162-164

9. Pillans PI, Boyd IW. Toenails and agranulocytosis. Intern Med J 2007;37:572-575

10. Gupta AK, Soori GS, Del Rosso JQ, Bartos PB, Shear NH. Severe neutropenia associated with oral terbinafine therapy. J Am Acad Dermatol 1998;38:765-767.

11. Ornstein DL, Ely P. Reversible agranulocytosis associated with oral terbinafine for onychomycosis. J Am Acad Dermatol 1998;39:1023-1024

12. Shapiro M, Li LJ, Miller J. Terbinafine-induced neutropenia. Br J Dermatol 1999;140:1196-1197. 
13. Conjeevaram G, Vongthavaravat V, Sumner R, Koff RS. Terbinafine-induced hepatitis and pancytopenia. Dig Dis Sci 2001;46:1714-1716.

14. Aguilar C, Mueller KK. Reversible agranulocytosis associated with oral terbinafine in a pediatric patient. J Am Acad Dermatol 2001;45:632-634.

15. Kovacs MJ,AlshammariS, Guenther L, Bourcier M. Neutropenia and pancytopenia associated with oral terbinafine. J Am Acad Dermatol 1994;31:806.

16. Tsai $\mathrm{HH}$, Lee $\mathrm{WR}, \mathrm{Hu} \mathrm{CH}$. Isolated thrombocytopenia associated with oral terbinafine. Br J Dermatol 2002;147:627628.

17. Grunwald MH. Thrombocytopenia associated with oral terbinafine. Int J Dermatol 1998;37:634.

18. Scheinberg P. Aplastic anemia: therapeutic updates in immunosuppression and transplantation. Hematology 2012;2012:292-300.
19. Guinan EC. Diagnosis and management of aplastic anemia. Hematology 2011;2011:76-81.

20. Calado RT, Garcia AB, Falcão RP. Decreased activity of the multidrug resistance P-glycoprotein in acquired aplastic anaemia: possible pathophysiologic implications. $\mathrm{Br} \mathrm{J}$ Haematol 1998;102:1157-1161.

21. Calado RT, Garcia AB, Gallo DA, Falcão RP. Reduced function of the multidrug resistance P-glycoprotein in CD34+ cells of patients with aplastic anaemia. Br J Haematol 2002;118:320326.

22. Mizuno K, Fukami T, Toyoda Y, Nakajima M, Yokoi T. Terbinafine stimulates the pro-inflammatory responses in human monocytic THP-1 cells through an ERK signaling pathway. Life Sci 2010;87:537-544.

23. Mintzer DM, Billet SN, Chmielewski L. Drug-induced hematologic syndromes. Adv Hematol 2009;2009:495863. 